Article

\title{
Between Fakes, Forgeries, and Illicit Artifacts-Authenticity Studies in a Heritage Science Laboratory
}

\author{
Stefan Simon $1,2, *$ (D) and Stefan Röhrs ${ }^{2}$ \\ 1 Global Cultural Heritage Initiatives, Yale University, New Haven, CT 06520, USA \\ 2 Rathgen-Forschungslabor, Staatliche Museen zu Berlin, Stiftung Preußischer Kulturbesitz, 14059 Berlin, \\ Germany; s.roehrs@smb.spk-berlin.de \\ * Correspondence: stefan.simon@yale.edu; Tel.: +1-203-436-2544
}

Received: 21 March 2018; Accepted: 22 May 2018; Published: 5 June 2018

check for updates

\begin{abstract}
Since its inauguration in 1888, the Rathgen Research Laboratory of the National Museums in Berlin has been challenged by authenticity questions on cultural heritage objects. In the setting of an ever-growing market, often intertwined with the increasing global impact of illicit traffic, scientific investigations can contribute equally to art-historical, or archaeological expertise when solving questions of authenticity, and should therefore always be included when significant values are at stake. Looted or stolen artifacts, copies, fakes, and forgeries have been an intrinsic element of the market since ever, and only selectively addressed in a trans-disciplinary, more holistic way. This paper makes the case for a reliable, state-of-the-art analysis and illustrates the potential benefits of such a scientific approach to authenticity questions in selected examples: 1. the case of German art forger, Wolfgang Beltracchi; 2. brass objects of alleged Benin and Ife provenance.
\end{abstract}

Keywords: authenticity; painting; fake/forger; metal alloy; heritage science; conservation science

\section{Introduction}

Over the past 150 years, the rapid progress of archaeological and historic sciences, in combination with increased mobility and logistics, significantly facilitated the growing transfer of cultural artifacts from so-called source countries into market countries (for definitions, see Mackenzie 2005), mainly Europe and the United States. This transfer soon emerged as what is discussed nowadays as illicit traffic (Yates 2016; Brodie and Renfrew 2005).

In fact, the transport of works of art across state boundaries is much easier than the transfer of money (Guillotreau 1999). The links to international crime, and even terrorism, became undisputed with the ongoing growth of illicit traffic, and are addressed by law enforcement agencies internationally (Lacoursière and Talbot 2005). Several UN Security Council Resolutions (e.g., 1483/2003, 2199/2015, 2347/2017) and EU Council Regulations (e.g., 1332/2013, 1210/2003) have been dedicated to the struggle with illicit traffic, especially in the MENA region, Syria, and Iraq.

Next to illicit traffic, forgeries, and fakes are another characteristic element of this market, one could consider it the other side of the same coin, ranging from antiquities to 21st century art. Already, Horace wrote, "He who knows a thousand works of art, knows a thousand forgeries" (Hoving 1997).

Questions about authentication (dating and clarification of provenance) are usually addressed by heritage science laboratories. The Rathgen Research Laboratory, the guiding institution for conservation science, art technology, and archaeometry of the National Museums in Berlin, has been involved in the authentication of cultural artifacts since its founding in 1888 and has built up respective material databases (Simon 2007). 
Conclusive answers to questions of authenticity can only result, if at all, through close collaboration between scientists, conservators, archaeologists, and art historians in a truly interdisciplinary effort. However, there are also ethical issues connected to such studies, which have been discussed in depth by Argyropoulos et al. $(2011,2014)$.

There is an undisputed need for reliable, state-of-the-art analysis in authentication issues. However, by epistemological principle, it is impossible to provide evidence for originals, often to the disappointment of collectors and museum curators: as the making of a "perfect fake" cannot be excluded, at least theoretically, final evidence in the laboratory can only be obtained on copies, fakes, and forgeries.

Some heritage science laboratories have developed policies on such analyses. The Rathgen Research Laboratory implemented the Berlin Resolution (2003) into its institutional policy for all cultural artifacts, whether they are modern or ancient. Since 2005, analytical services have been offered only on the premise that the rightful provenance of an object is ascertained. This policy, which was initially met with considerable resistance, even from within the institution, is anticipating respective federal legislation on the import of cultural property by more than a decade (Kulturgutschutzgesetz 2016).

Consequently, the Rathgen Research Laboratory has focused on collaborating with law enforcement agencies and international bodies in order to contain the further growth of illicit trafficking of art and the detection of fakes and forgeries.

In authenticity analysis, the presence of specific pigments may serve as "terminus post quem" for dating evidence. "Terminus post quem" - meaning "point of time after which"-implies that the use of a pigment is only possible after its invention and introduction into the market. The scientific knowledge in this field needs to be expanded continuously and new markers need to be identified, especially for the second half of the 20th century, in order to maintain an advantage over the forgers, who closely follow the scientific progress in the analytical approach used and constantly "improve" their work.

Beyond the first use of a pigment and modifications in its production process, causing small changes in its properties moves it into the focus of analytical interest. Unfortunately, manufacturers and vendors are not overly enthusiastic about sharing information on their current products, and for older products, it is often not easy to retrieve this information from archival resources.

Additionally, a good awareness of the respective detection limits and accuracies of the analytical technique applied remains a crucial element in the process, especially when the results are evaluated in a quantitative way. The use of complimentary methods is always an asset, as is a step-wise progress from non-destructive methods toward those requiring a sample.

This paper illustrates an approach to scientific research in authenticity questions on two selected examples.

1. The Wolfgang Beltracchi Case of forged paintings.

2. Brass objects of alleged Benin/ Ife provenance.

\section{Results}

\subsection{The Wolfgang Beltracchi Case of Forged Paintings}

Between 2010 and 2011, the Rathgen Research Laboratory was tasked with investigating 7 out of 14 paintings that were at the core of the charges against the German group of forgers around Wolfgang Beltracchi, who had presumably sold over 50 faked art works attributed to Max Ernst, Max Pechstein (Figures 1 and 2), Heinrich Campendonk, André Derain, Fernand Léger, and Kees van Dongen to the art market. After the arrest of the forgers in September 2010, the lawsuit in Cologne finished with the verdict a year later in October 2011.

Not only was the scale of the case and the damage caused to the art marked unprecedented, but so to was the effort of the group to produce convincing art works with a conclusive background story. For all these paintings, supposedly dating from the period between 1905 to 1927, old canvases and 
stretchers had been used. Additionally, in the choice of the artist materials, the forgers were aiming at matching the materials available at the time. Building on a detailed technical survey, a wide range of analytical methods were used for investigating the paintings, which, in conclusion, were able to deliver solid evidence that allowed excluding a pre-1930's date of the paintings and unmasking them as forgeries.

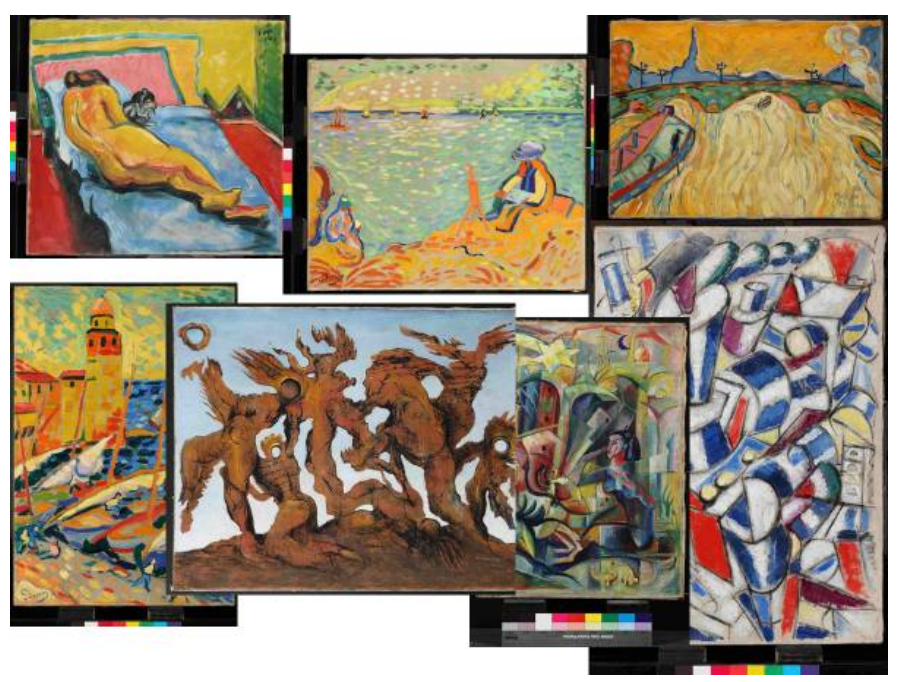

Figure 1. Overview over the seven paintings of the Beltracchi case, with their attributions from upper left clockwise: "Liegender weiblicher Akt mit Katze”, Hermann Max Pechstein, 1909; “Mattisse peignant à Collioure", André Derain, 1905; "Seinebrücke mit Frachtkähnen”, Hermann Max Pechstein, 1908; “Kubistisches Stillleben”, Fernand Leger, 1913; "Landschaft mit Figuren und Vogel—gewidmet Else Lasker-Schüler”, 1914; “La Horde, Max Ernst, 1927; “Collioure”, André Derain, 1905-1910 (photos: Christoph Schmidt).

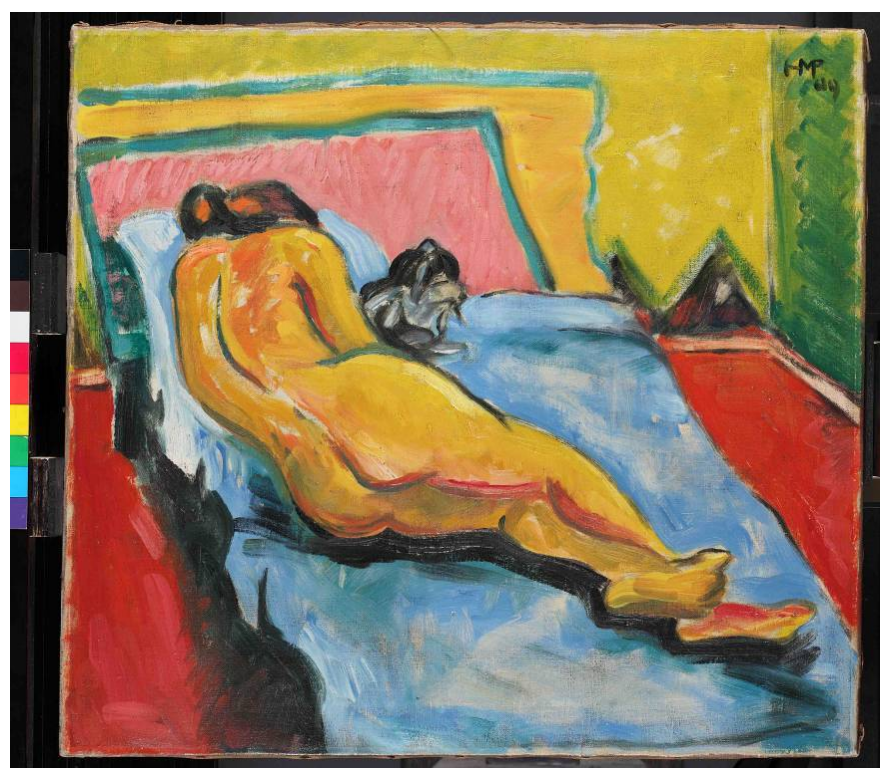

Figure 2. Painting allegedly attributed to Hermann Max Pechstein (1881-1955), “Liegender weiblicher Akt mit Katze" (1909); signature on upper right: "HMP 1909"; oil on canvas; stretcher frame, H $55.4 \mathrm{~cm} \times$ B $60.2 \mathrm{~cm}$ (photo: Christoph Schmidt).

Multispectral imaging and micro X-ray fluorescence ( $\mu$-XRF) were used to examine the paintings in the first step. The multispectral imaging allowed for identifying restored and overpainted areas, 
and distinguishing different paint formulations that sometimes appear similar to the human eye. An important element of the analytical protocol has been a careful technological investigation by microscopy, which revealed very specific features of the fake paintings. Further evidence was obtained, for example, by dendrochronological investigation of the stretcher frame. After the $\mu$-XRF analysis for element detection, samples were taken from selected areas for further investigation by microchemical spot tests, Fourier transform infrared (FT-IR), and Raman spectroscopy. A number of pigments were identified; among them, cinnabar, lead chromate, ultramarine, zinc white, titanium white, and copper phthalocyanine blue. Most of the pigments found did not contradict the alleged production date of the paintings. Of critical significance, however, is the occurrence of the pigments titanium white and copper phthalocyanine blue.

The presence of the latter has been proven by two alternative methods: microchemical spot test (Figure 3) and Raman spectroscopy (Figure 4). The microchemical test is based on a color reaction of the pigment with sulfuric acid, which causes the color to change to yellow or yellow-green (De Keizer 1990; Kalsbeek 2005). A characteristic feature of phthalocyanine blues is that they regain their blue color after the addition of water (Lutzenberger and Stege 2009; Kühn and Thieme 2009).
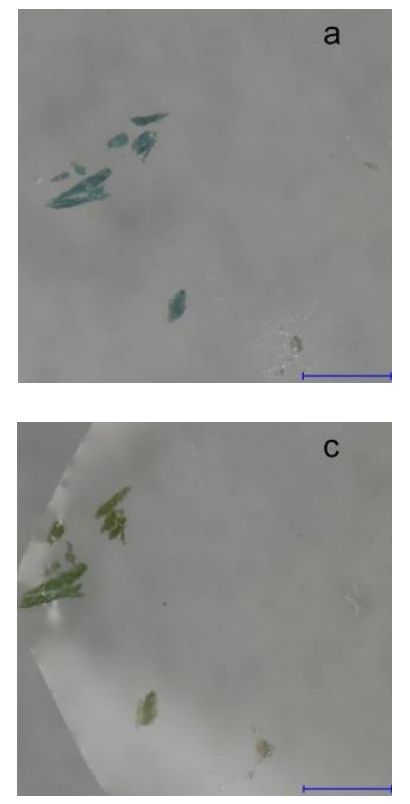
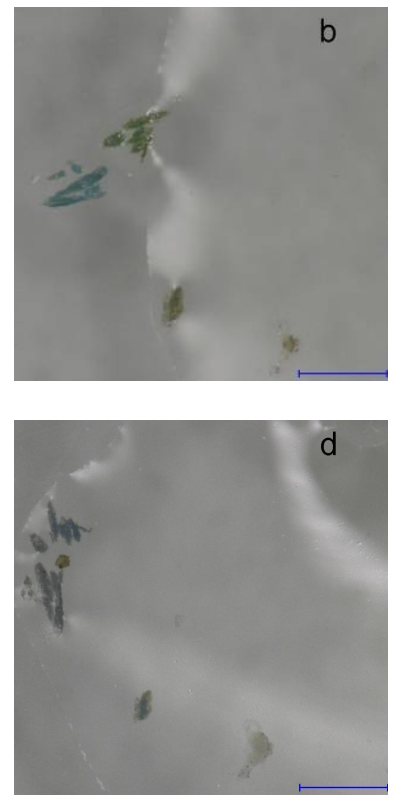

Figure 3. Images of the microchemical test on a blue paint sample. (a) The pigment before the test; (b) paint particles in contact with sulfuric acid; (c) color of particles has changed to yellow-green; and (d) after diluting the acid, the blue color returns. The scale bar is $250 \mu \mathrm{m}$.

However, phthalocyanine blue, a synthetic organic pigment detected in blue and green paint layers, is unlikely to be part of paint layers predating 1934 (Eastaugh et al. 2004; Römpp 1995; Quillen Lomax 2005). After A.V Braun and J. Tcherniak isolated the first metal free phthalocyanine as a side product in 1907 (Braun and Tcherniac 1907), the first copper phthalocyanine was synthesized by H. de Diesbach and E. von der Weid in 1927 (De Diesbach and Weid 1927). Scottish Dye Works patented copper phthalocyanine in 1929 (British Patent 1928, cited after Dalhen 1935). The commercial use of this pigment started in 1935 (Eastaugh et al. 2004).

Titanium dioxide, known as white pigment titanium white, can also not be expected in painting technology before 1930. Today still, it is applied broadly and forms part of many oil colors, often in small admixtures due to its high efficiency. The introduction of titanium white into the market is discussed extensively in the literature, especially by Laver (1997). An early reference to "Blanc de Titan" appears 1924 in the Encyclopédie de Chimie Industrielle (Coffignier 1924). It refers to the discovery of titanium oxide (rutile) containing paints for ship bottoms or other surfaces exposed to sea 
water by John W. Overton in the 1870s ( British Patent(1893), in a mixture with bituminous compounds, hence not as a white pigment. Earlier titanium green, a titanium hexacyanoferrate, was discovered by Frederick Versmann (British Patent 1861). Titanium is also a regular compound of other earth paints, such as ochres or some greens, because of the presence of ilmenite. Therefore, elemental analysis alone (e.g., by XRF or environmental scanning electron microscopy-energy dispersive X-ray (ESEM/EDX) analysis) cannot provide sufficient evidence in authenticity questions and needs to be combined with methods for phase and compound analysis.

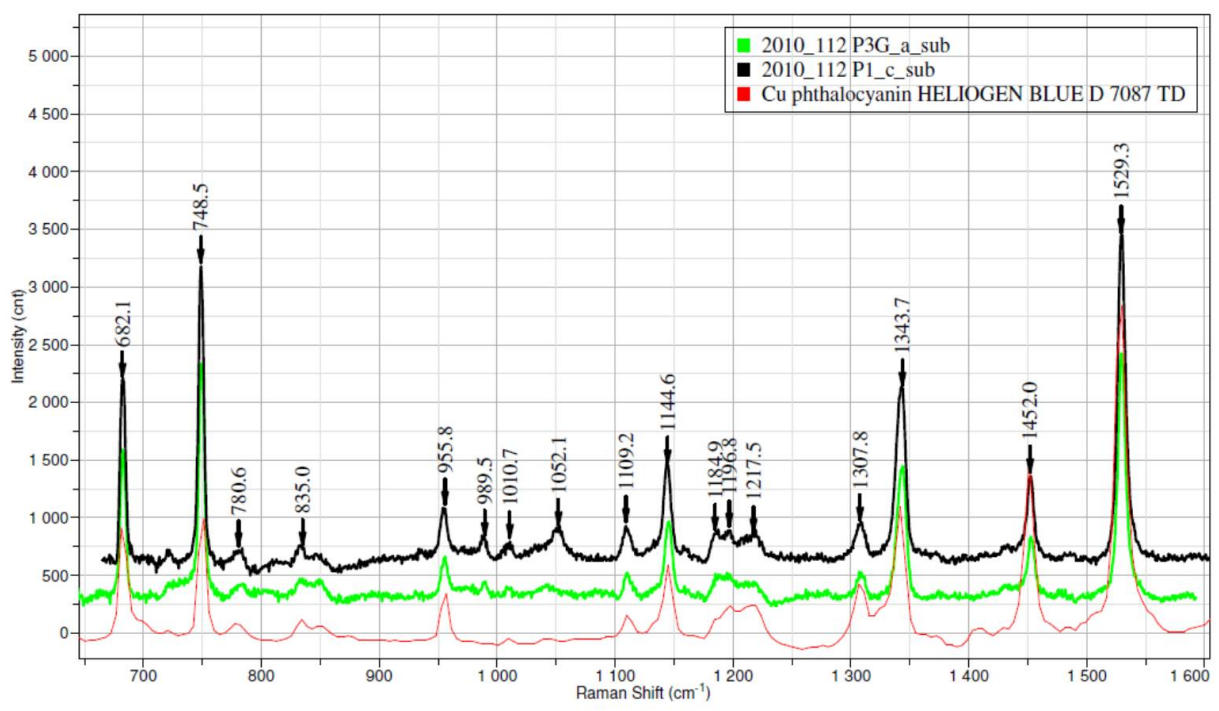

Figure 4. Raman Spectra for two blue paint samples with reference (in red) Heliogen Blue (copper phthalocyanine blue).

The first patents for the production of titanium whites date back to 1913 and are converted from Norwegian patents in the following years (Deutsche Patentschrift 1913,1917a, 1917b), as well as from U.S. patents (Deutsche Patentschrift 1917c, 1917d). Their introduction into the market was slow, both the paint industry and artists' color makers remained skeptical about their performance. The early formulations of titanium dioxide pigments in the 1920s were composites, mainly mixed with barium sulphate, zinc oxide, or lithopone. Its most early use in the pure anatas modification can be traced back to 1925, according to (Laver 1997). The marketing of titanium white (on the basis of the more stable rutile modification) started even later (U.S. Geological Survey 2007). Hering (2000) describes 1938 as "terminus post quem" for the first use of titanium white in rutile modification. Figure 5 gives an overview over the development of the market volume, which really started soaring only after World War II.

The evidence for the "terminus post quem" markers phthalcyanine blue and Rutile in original paint layers helped, in addition to further evidence (e.g., dendrochronological data on the stretcher frames or a comparative analysis of the used nails), to exclude the alleged production dates of these paintings.

\subsection{Brass Objects of Alleged Benin/Ife Provenance}

Metallic zinc was not available in Europe before the end of the 18th century. Therefore, the production of brass alloys was performed by the cementation process, in which metallic copper was heated with calamine, a zinc ore. For technological reasons, the cementation process reveals alloys with a limited zinc content (Haedecke 1973). Because of the dependencies between the diffusion of zinc gas in the solid copper matrix, the upper limit for zinc content ranges between $28-32 \%$, and varies with the process conditions (Haedecke 1973; Craddock 1995; Pollard and Heron 1996; Lambert 1997; Riederer 2004). 


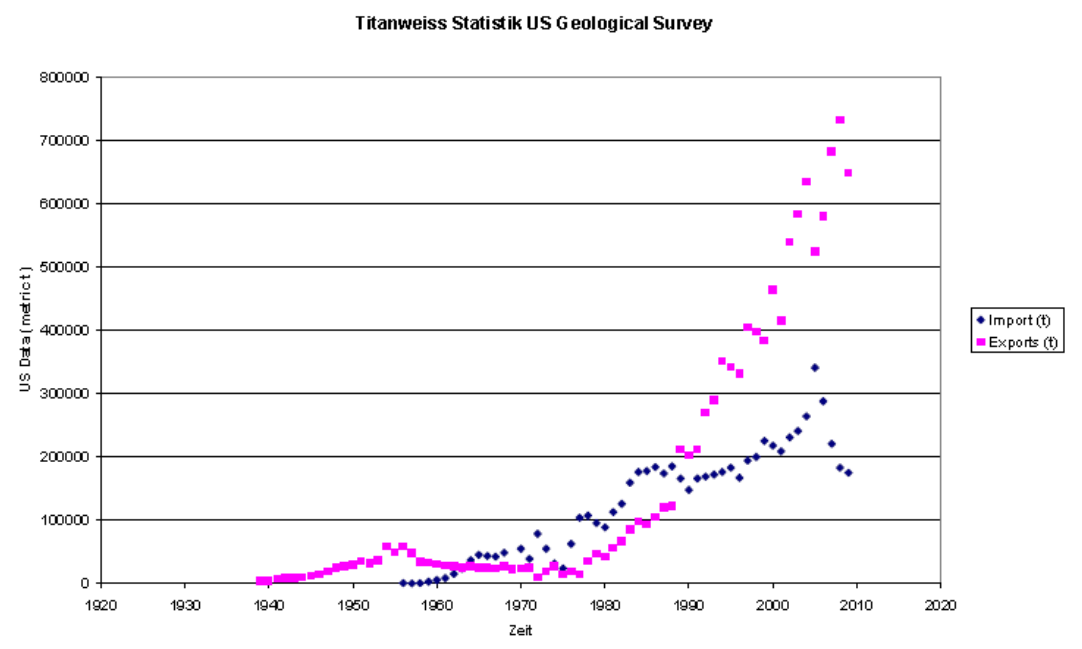

Figure 5. Chronology of import and export of titanium dioxide pigments for the United States (U.S. Geological Survey 2007).

The brass founder, Nehemiah Champion, registered Patent No 454 in 1723 for a better cementation process, based on a finer granulation of the copper metal (Day and Tylecote 1991). This allows for a faster diffusion of zinc vapor in the copper matrix and raises the maximum zinc content to approximately $33.3 \%$. This seems to be the maximum zinc concentration reachable in brass by the cementation process. In experimental tests of this process, the composition of the obtained brass alloys shows between 13-31\% zinc (Doridot et al. 2006). Some studies, however, predict zinc contents up to $40 \%$ (Welter 2003; Ullwer 2001; Zwicker et al. 1985). Only through addition of metallic zinc to the melting process-a technology not known in Europe, but known in some parts of Asia-zinc contents of $39-45 \%$ could be achieved, for example, as early as 1601 in brass astrolabia in Lahore (Newbury et al. 2006).

Although metallic zinc appears in Europe around 1700, and zinc-rich brasses appear more often after 1800, zinc-rich brasses with contents exceeding 30\% could be found at times in Europe. According to Riederer (2004), this was a result of used raw materials, such as metallic zinc, imported via the East India Company (zinc distillation was known in India as early as the 15th century) or from smelting sites in Central Germany, such as the Harz, where metallic zinc was obtained by condensation on colder parts of the oven during the metallurgic processing of zinc ores. This might explain the use of zinc-rich brasses for musical instruments in the 16-17th century.

The evaluation of trace elements, such as cadmium, indium, silver, or iron, is difficult. Potential re-use of older alloys in later production processes can have an enormous impact on whether these data can be used for establishing a context for provenance and trade of raw materials (Pollard and Heron 1996).

A study by Manescu et al. (2008) on brass elements in organ pipes shows that before 1750 in Europe, these always contain lead. The average lead content then slowly decreases from 7-8\% (1624) to ca. $2 \%$ in the mid-18th century. The first "lead-free" parts appear around 1750. After 1820, lead completely disappears from brass alloys. This is probably a consequence of the fact that lead increases the brittleness of the alloy and hence may disturb the production process. Manescu et al. (2008) also describe the increase of zinc contents to over $30 \%$ after 1750 .

In conclusion, zinc contents significantly above $30 \%$ can be attributed to production in the 19th or later 18th century. Brasses of recent origin are not only characterized by high zinc contents, but also by significant cadmium contents. According to the compositional analysis data collected in the Rathgen Research Laboratory database, the cadmium content of brasses produced by the traditional cementation process is always below $0.002 \%$. Higher cadmium contents may indicate the use of metallic zinc in the smelting process. 
The Berlin database of metal analysis and cultural artifacts at the Rathgen Research Laboratory comprises more than 17,000 objects, among them approximately 500 are attributed to Benin provenance. Technological features - as well as the receding limitations in the zinc content in brass over the course of the 19th century-and the compositional difference between well-provenanced objects in museum collections, compared with objects originating from the art market (collectors), help indicate fakes and facilitate dating. Generally, the majority of those objects derived from the art market differ significantly in their elemental composition from those with better provenance.

Six objects of alleged Nigerian (Benin and Ife) and Mali provenance, attributed to the Paul Garn Collection Dresden (allegedly purchased 1920 or 1920-1940 (Object 1)) and dated from ca. 1430 to 1650 AD, were subject to a technological study in 2012 (Figure 6). Figure 7 shows the example of a documentation of the core sample for an object. The results of the atomic absorption spectrometry (AAS) analysis are summarized in Table 1. Objects 1, 2, and 6 show an increased zinc content, which contradicts the alleged dating in the 15 th or 17 th century, respectively. Objects 1, 2, 3, 5, and 6 show an increased cadmium content, which is an indication for post-1900 production. Contents of iron and nickel are surprisingly high in object 4.

Figure 8 shows the zinc/tin ratios in Mass\%, determined by AAS, for objects of Benin provenance in the database of the Rathgen Research Laboratory. The ratios differ significantly for privately owned (PRIV) from those in the public collections of Berlin (B), Dresden (D), Cologne (K), Leipzig (L), Munich (M), and Stuttgart (S). Objects in private possession usually show a higher zinc and tin content, which reveals them as modern copies. All but object 4 are well fitted in this group. In Figure 9, the respective zinc/lead ratios of the Benin complex are shown. Two separate clusters of alloys are visible: one high in $\mathrm{Zn}$, but low in $\mathrm{Pb}$ - content; the other with a rather constant $\mathrm{Zn} / \mathrm{Pb}$ ratio. Most privately-owned objects fall into the first group, with lower lead concentrations, a trend that points toward a more recent production date, according to Manescu et al. (2008).

Table 1. Results of atomic absorption spectrometry (AAS)-analysis (in Mass $\%, \mathrm{Cu}=100 \%-\Sigma \%$ all other elements) (concentrations contradicting alleged production date are indicated in yellow).

\begin{tabular}{|c|c|c|c|c|c|c|c|c|c|c|c|c|c|}
\hline Object & $\mathrm{Cu}$ & Sn & $\overline{\mathrm{Pb}}$ & Zn & $\mathrm{Fe}$ & $\mathbf{N i}$ & Ag & $\overline{\mathrm{Sb}}$ & $\overline{\text { As }}$ & $\overline{\mathbf{B i}}$ & Co & $\overline{\mathrm{Au}}$ & $\mathrm{Cd}$ \\
\hline 1 & 62.50 & 1.34 & 3.34 & 32.19 & 0.253 & 0.277 & 0.025 & 0.078 & $<0.10$ & $<0.025$ & $<0.01$ & $<0.02$ & 0.005 \\
\hline 2 & 62.88 & 1.40 & 3.12 & 31.81 & 0.446 & 0.323 & 0.024 & $<0.05$ & $<0.10$ & $<0.025$ & $<0.01$ & $<0.02$ & 0.005 \\
\hline 3 & 64.36 & 1.26 & 3.36 & 30.32 & 0.397 & 0.285 & 0.016 & $<0.05$ & $<0.10$ & $<0.025$ & $<0.01$ & $<0.02$ & 0.004 \\
\hline 4 & 75.18 & 0.81 & 2.00 & 19.36 & 0.904 & 1.720 & 0.020 & $<0.05$ & $<0.10$ & $<0.025$ & $<0.01$ & $<0.02$ & 0.002 \\
\hline 5 & 63.49 & 1.62 & 5.55 & 28.41 & 0.313 & 0.312 & 0.023 & 0.153 & 0.132 & $<0.025$ & $<0.01$ & $<0.02$ & 0.004 \\
\hline 6 & 60.55 & 0.90 & 3.58 & 33.62 & 0.892 & 0.314 & 0.031 & $<0.05$ & 0.103 & $<0.025$ & $<0.01$ & $<0.02$ & 0.003 \\
\hline
\end{tabular}

Table 2 presents compositional data obtained by ESEM/EDX for object 4 . There is sufficient correlation in the results obtained by ESEM/EDX and AAS for the main elements. Discrepancies for lead, iron, and nickel contents can be attributed to their inhomogeneous allocation in the alloy texture. Furthermore, objects 2 and 4 contain aluminum, phosphor, and silicon in significant concentrations-all elements of modern alloys-which indicates post-19th/20th century production. According to Schwab et al. (2007), aluminum, known since 1827, is added to increase the oxidation and wear resistance of the alloy and is a common constituent in modern brasses in the range of 0.2 to $0.7 \%$.

In conclusion, the alleged dating between 1430 and 1650 could be excluded for all investigated objects.

Table 2. Results of environmental scanning electron microscopy-energy dispersive X-ray analysis (ESEM/EDX) (object 4) (concentrations contradicting alleged production date are indicated in yellow).

\begin{tabular}{cccccccccc}
\hline Measurement Spot & $\mathbf{C u}$ & $\mathbf{S n}$ & $\mathbf{P b}$ & $\mathbf{Z n}$ & $\mathbf{F e}$ & $\mathbf{N i}$ & $\mathbf{A l}$ & $\mathbf{S i}$ & $\mathbf{P}$ \\
\hline $1(\mathrm{M} \%)$ & 74.4 & 1.2 & 0.7 & 19.3 & 1.1 & 2.0 & 1.3 & 0.1 & 0.03 \\
\hline $2(\mathrm{M} \%)$ & 72.4 & 0.9 & 0.1 & 22.3 & 1.7 & 1.1 & 1.5 & 0.2 & 0.01 \\
\hline $3(\mathrm{M} \%)$ & 73.1 & 1.2 & 1.0 & 19.6 & 1.5 & 1.8 & 1.3 & 0.3 & 0.21 \\
\hline Mean $(\mathrm{M} \%)$ & 73.3 & 1.1 & 0.6 & 20.4 & 1.4 & 1.6 & 1.3 & 0.2 & 0.08 \\
\hline
\end{tabular}




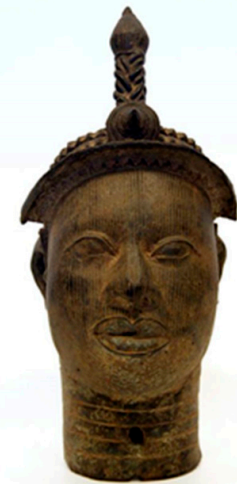

(1)

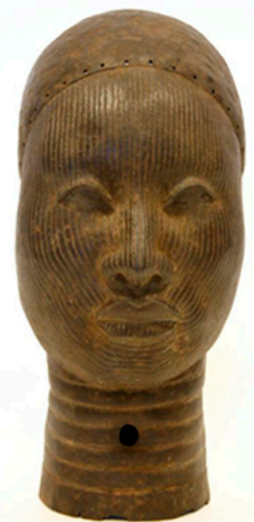

(4)

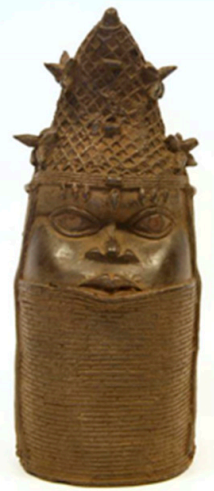

(2)

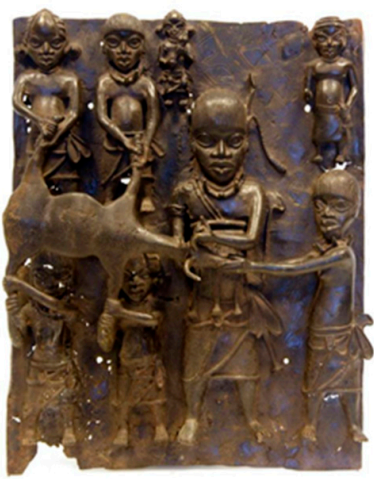

(5)

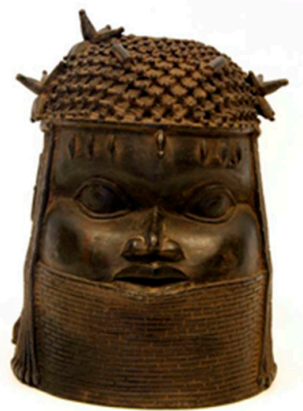

(3)

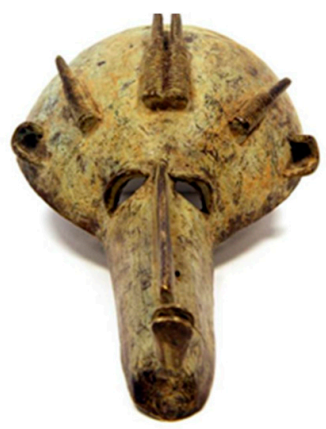

(6)

Figure 6. Various brass objects of alleged Benin and Ife provenance (photo: Andreas Schwabe). Top, from left to right (1) (93) Oni (Ife) head, ca. 1450; (2) (89.2) Queen Mother (Benin), ca. 1650; (3) (89.3) head with coral hood (Benin), ca. 1600; (4) (100) Ife head, ca. 1430; (5) (58.2) relief with animal sacrifice (Benin), ca. 1620; (6) (39) mask (Mali?), ca. 1650.

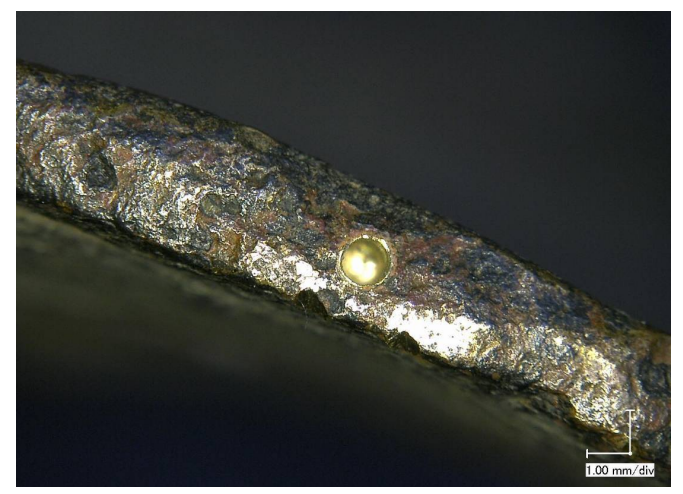

(a)

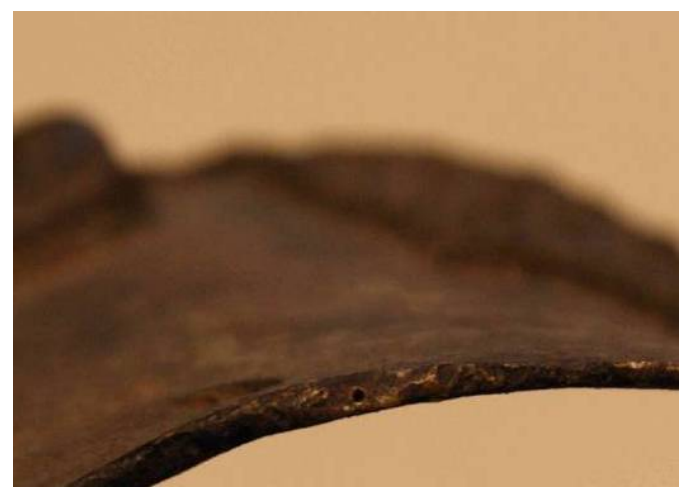

(b)

Figure 7. Documentation of sample location (object 1), Oni Head, alleged Ife provenance, the photo (a) on the left is a macroscopic detail of the overview photo (b) on the right. 


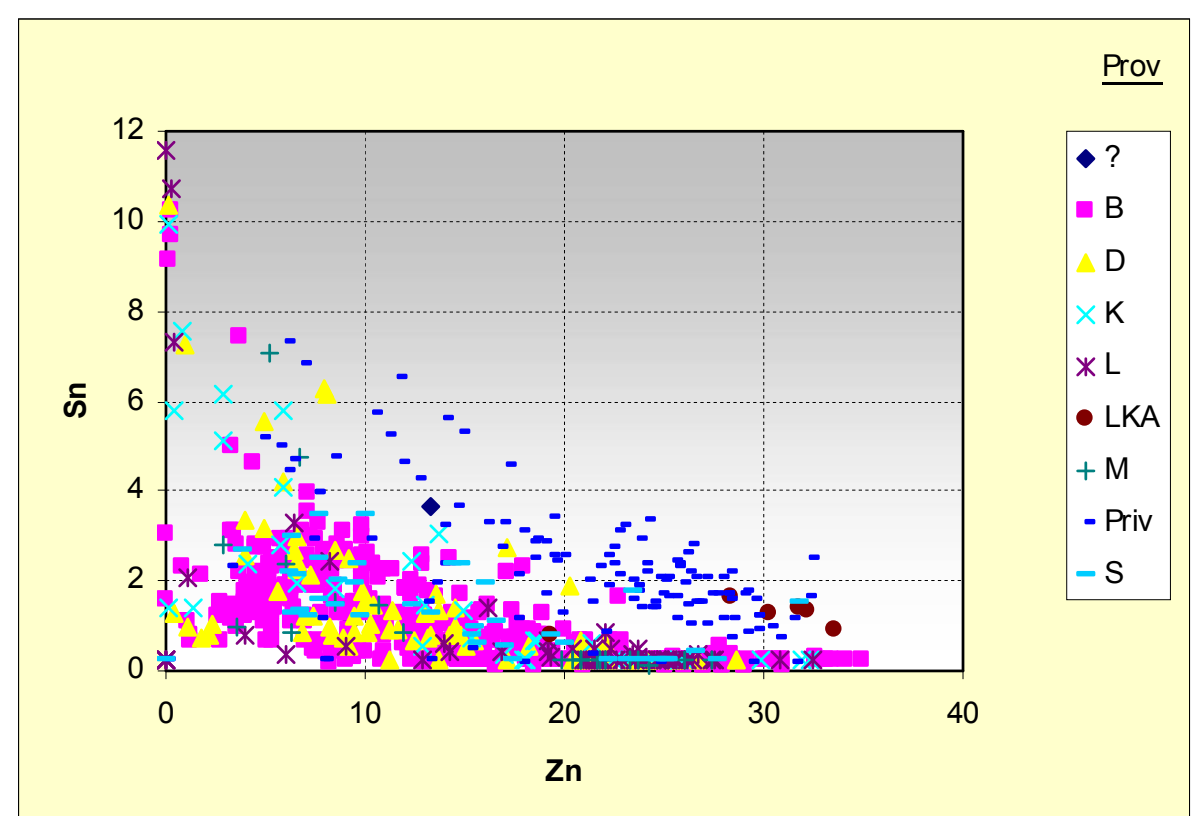

Figure 8. Tin content $(\mathrm{M} \%)$ as a function of zinc content $(\mathrm{M} \%)$ determined by atomic absorption spectrometry (AAS) for bronze and brass objects of presumable and certain Benin provenance (Rathgen Research Laboratory Database. B,D,K,L,M,S: public museum collections, Priv: private collectors, LKA: group of investigated objects).

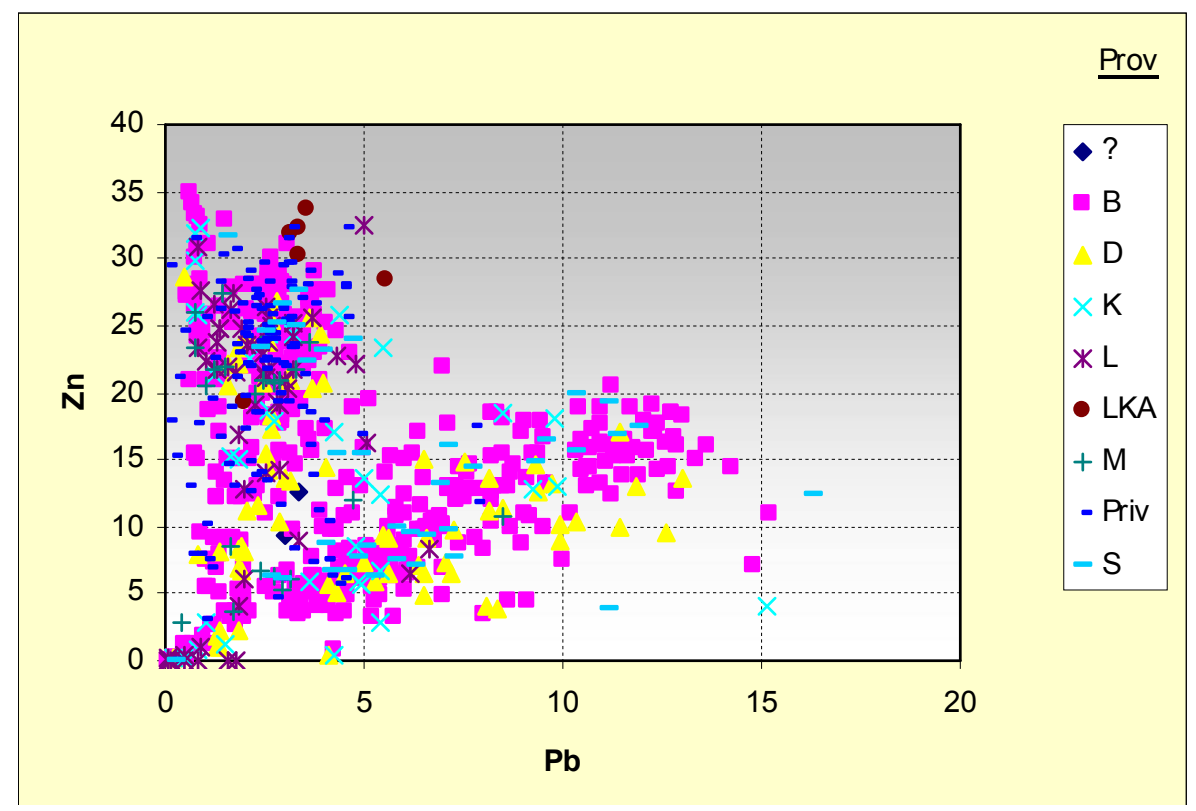

Figure 9. Zinc content (M\%) as a function of lead content (M\%) determined by AAS for bronze and brass objects of presumable and certain Benin provenance (Rathgen Research Laboratory Database. B,D,K,L,M,S: public museum collections, Priv: private collectors, LKA: group of investigated objects).

\section{Discussion}

In the setting of an ever-growing market, deeply intertwined with the increasing global impact of illicit trafficking, scientific investigations may contribute equally to other professional expertise for solving questions related to the authenticity of cultural artifacts. They should, therefore, always be included in the due diligence process when significant values are at stake. 
While looted or stolen artifacts, copies, fakes, and forgeries have been an intrinsic element of the market since a long time ago, the related questions have only been selectively addressed in a trans-disciplinary, more holistic way.

In general, once a work of art is accepted to the laboratory, anamnesis-the investigation of its history and provenance-is the first step to be taken, and is of key importance to the process as a whole.

This step should be followed by a whole cascade of analytical methods, starting from non-destructive imaging technologies, to micro-sampling and subsequent chemical analysis. The aim is to look for inconsistencies, such as unusual metal components in alloys or pigments with a "terminus post quem" in paintings.

The two cases discussed in this study illustrate how scientific laboratories with their respective expertise are well positioned to provide crucial information and help assemble evidence for legal cases in the accelerating race between various stakeholders of the art black market on the one side, and law enforcement agencies on the other.

The analytical technologies and scientific landscape are continuously changing and developing. Thus, on the one hand-and this works to the advantage of law enforcement-tomorrow we shall have better tools, and more sensitive and innovative methods at our disposal. Meanwhile, the forgers, once their products have left their hands, cannot interfere with them anymore.

On the other hand, the scientific knowledge in this field needs to be expanded continuously and new markers need to be identified, especially for the second half of the 20th century, in order to maintain an advantage over the forgers, who closely follow the scientific progress in the analyses used and constantly "improve" their work.

Most importantly, this requires an increased public understanding of the need to act in a more collaborative effort across a broad variety of disciplines, which include provenance research, criminology, and heritage science. This understanding will hopefully lead to a renewed public commitment to invest in research and education, respective staff positions, and innovative infrastructure and equipment across market and source countries, all essential conditions for not losing this race in the realm of cultural heritage preservation.

\section{Materials and Methods}

\subsection{Raman Spectrometry}

Raman spectra were measured with a Horiba XploRa Raman-microscope, equipped with a 532, 638, and $785 \mathrm{~nm}$ laser. Laser powers were at $25 \mathrm{~mW}(532 \mathrm{~nm}), 24 \mathrm{~mW}(638 \mathrm{~nm})$, and $90 \mathrm{~mW}(785 \mathrm{~nm})$. For measurements of the samples, a filter with $10 \%$ or $1 \%$ transmission was used, mostly in combination with a 50x objective with a long working distance.

\subsection{Atomic Absorption Spectrometry (AAS)}

Atomic absorption spectrometry was performed on a PU 9100 (Philips) in an air/acethylen flame in continuous mode, with background compensation (deuterium bulb); the detection limit for specific elements varies with wavelength and input. Twenty milligram bore chips (1 mm drill bit) (Figure 7) were dissolved in nitric and hydrochloric acid and diluted in water to $20 \mathrm{~mL}$. From this solution, 12 elements were measured, the difference from $100 \%$ was expressed as the copper content. The drill holes were filled afterwards with a patina/wax mixture to blend in with their surroundings.

\subsection{Environmental Scanning Electron Microscopy-Energy Dispersive X-ray Analysis (ESEM/EDX)}

Selected bore chips were embedded for cross sections in order to allow for the analysis of elements and their local distribution in the alloy. The investigation of these surfaces, combined with selective element analysis, was accomplished by scanning electron microscope Quanta 200 (Fei) in environmental mode. EDX for semi-quantitative analysis involved X-ray analyzer XFlash 4010 (Bruker axs). 
Author Contributions: S.S. drafted the manuscript and S.R. revised it critically. Both authors read and approved the final manuscript.

Acknowledgments: Collaboration and support of René Allonge, Markus Schönfelder and Thomas Walter from the art squad of the Berlin State Office of Criminal Investigation (LKA) is gratefully acknowledged. Special thanks go to Cristina Lopes Aibéo, Regine-Ricarda Pausewein, Joseph Riederer †, Andreas Schwabe and Sabine Schwerdtfeger at the Rathgen Research Laboratory for their close collaboration and always fruitful discussions, as well as to Christoph Schmidt from the Gemäldegalerie, National Museums Berlin for photography and Petra Winter from the Central Archives, National Museums Berlin for leading the provenance research.

Conflicts of Interest: The authors declare no conflict of interest. The founding sponsors had no role in the design of the study; in the collection, analyses, or interpretation of data; in the writing of the manuscript, and in the decision to publish the results.

\section{References and Notes}

Argyropoulos, Vasilike, Kyriaki Polikreti, Stefan Simon, and Dimitris Charalambousa. 2011. Ethical issues in research and publication of illicit cultural property. Journal of Cultural Heritage 12: 214-19. [CrossRef]

Argyropoulos, Vasilike, Eleni Aloupi-Siotis, Kyriaki Polikreti, Rea Apostolides, Wafaa El Saddik, Raymund Gottschalk, Mona Abd el Nazeer, Marina Vryonidou-Yiangou, Peter Ashdjian, Maria-Christina Yannoulatou, and et al. 2014. Museum Education and Archaeological Ethics: An Approach to the Illicit Trade of Antiquities. Journal of Conservation and Museum Studies 12: 1-8.

Berlin Resolution. 2003. Available online: https://www.preussischer-kulturbesitz.de/fileadmin/user_upload/ documents/mediathek/schwerpunkte/provenienz_eigentum/rp/berliner_resolution_2003_engl.pdfandhttps: / /ipch.yale.edu/sites/default/files/files/Berlin_Resolution_2003.pdf (accessed on 21 March 2018).

Braun, A., and J. Tcherniac. 1907. Über die Produkte der Einwirkung von Acetanhydrid auf Phthalimid. Berichte der Deutschen Chemischen Gesellschaft 40: 2709-14. [CrossRef]

British Patent 750. 1861. Colour for Dyeing, March 25.

British Patent 9825. 1893. An Improved Paint, December 23.

British Patent 322,169. 1928. Improvements in and Relating to the Manufacture and Use of Colouring Matters, May 16, No. 14,415/28.

Brodie, Neil, and Colin Renfrew. 2005. Looting and the World's Archaeological Heritage: The Inadequate Response. Annual Review of Anthropology 34: 343-61. [CrossRef]

Coffignier, Ch. 1924. Couleurs et Peintures, Encyclopédie de Chimie Industrielle. Edited by M. Matignon. Paris: Librairie J.B Ballière et fils, p. 234f.

Craddock, Paul T. 1995. Early Metal Mining and Production. Edinburgh: Edinburgh University Press, pp. $292-302$.

Dalhen, Miles A. 1935. The phthalocyanines, a new class of pigments and dyes. Industrial and Engineering Chemistry 31: 839-41.

Day, Joan, and R. F. Tylecote. 1991. The Industrial Revolution in Metals. London: The Institute of Metals, pp. $172-93$.

De Diesbach, Henri, and Edmond Von der Weid. 1927. Quelques sels complexes des o-dinitriles avec le cuivre et la pyridine. Helvetica Chimica Acta 10: 886-87. [CrossRef]

De Keizer, Matthijs. 1990. Microchemical Analysis on Synthetic organic Artists' Pigments discovered in the twentieth Century. In Preprints of the ICOM Committee for Conservation 9th Triennal Meeting Dresden. Edited by Kirsten Grimstad. Paris: ICOM Committee for Conservation, pp. 220-25.

Deutsche Patentschrift. 276025. 1913. Peder Farup, Drontheim, Norwegen, Verfahren zur Darstellung von Titansauerstoffverbindungen.

Deutsche Patentschrift. 307951. 1917a. Det Norske Aktieselskab for Elektrokemisk Industri, Kristiania-Verfahren zur Herstellung Weisser Farbstoffe.

Deutsche Patentschrift. 312090. 1917b. Titan CO.A./S., Kristiania-Verfahren zur Darstellung von Titanpigmenten. Deutsche Patentschrift. 337396. 1917c. Titanium Pigment Company, Inc., New York, V.St.A., Verfahren zur Gewinnung von Titanoxyd aus Titanhaltigen, Eisenschüssigen Stoffen.

Deutsche Patentschrift. 337397. 1917d. Titanium Pigment Company, Inc., New York, V.St.A., Verfahren zur Gewinnung von Titanoxyd aus Titan- und Eisenhaltigem Material. 
Doridot, Aurore, Luc Robbiola, and Florian Tereygeol. 2006. Production Expérimentale de Laiton par Cémentation en Creuset Ouvert, Avec du Minerai de Zinc, Selon les Recettes Médiévales et Modernes, ArchéoSciences [En ligne], 30 | 2006, Document 2, mis en Ligne le 31 Décembre 2008. Available online: http:/ / archeosciences. revues.org/index107.html (accessed on 21 March 2018).

Eastaugh, Nicholas, Valentine Walsh, Tracey Chaplin, and Ruth Siddall. 2004. The Pigment Compendium. Oxford: A Dictionary of Historical Pigments, pp. 298-99.

Guillotreau, Ghislaine. 1999. Art et Crime: La Criminalité du Monde Artistique, sa Répression. Paris: Presses Universitaires de France-PUF, 299p.

Haedecke, K. 1973. Equilibria in the Production of Brass by the Calamine Process. Erzmetall 26: 229-33.

Hering, M. H. Bernd. 2000. Weiße Farbmittel. Fürth. pp. 196-204.

Hoving, Thomas. 1997. False Impressions. The Hunt for Big-Time Art Fakes. New York: Simon and Schuster.

Kalsbeek, Nicoline. 2005. Identification of synthetic organic pigments by characteristic colour reactions. Studies in Conservation 50: 205-29. [CrossRef]

Kühn, Hermann, and Cristina Thieme. 2009. Konservierungswissenschaft-Mikrochemie, Lecture Notes 2009, TU München, München, Germany.

Gesetz zum Schutz von Kulturgut (Kulturgutschutzgesetz-KGSG). 2016. Kulturgutschutzgesetz vom 31. Juli 2016 (BGBl. I S. 1914), §§ 28, 32 KGSG.

Lacoursière, Alain, and Jean-François Talbot. 2005. Partenariat/la solution au trafic illicite d'oeuvres d'art. (Conclusion du projet pilote 2003-2005 de la police nationale du Québec). Paper presented at the 14th Triennial Meeting ICOM-CC, The Hague, The Netherlands, September 12-16; pp. 282-84.

Lambert, Joseph B. 1997. Traces of the Past Unraveling the Secrets of Archaeology through Chemistry. New York: Perseus Books, Reading Massachusetts, pp. 192-93.

Laver, Marilyn. 1997. “Titanium Dioxide Whites" Artists' Pigments. In A Handbook of their History and Characteristics 3; Edited by Elisabeth West FitzHugh. Oxford: National Gallery of Art, Washington and Oxford University Press, pp. 295-355.

Lutzenberger, Karin, and Heike Stege. 2009. From Beckmann to Baselitz-Towards and Improved Micro-Identification of Organic Pigments in Paintings of 20th Century Art. e-Preservation 6: 89-100.

Mackenzie, Simon R.M. 2005. Going, Going, Gone: Regulating the Market of Illicit Antiquities. Leicester: Institute of Art and Law, p. 290.

Manescu, A., F. Fiori, A. Giuliani, N. Kardjilov, Z. Kasztovszky, F. Rustichelli, and B. Straumal. 2008. Non-destructive compositional analysis of historic organ reed pipes. Journal of Physics: Condensed Matter 20: 104250. [CrossRef]

Newbury, B. D., M. R. Notis, B. Stephenson, G. S. Cargill III, and G. B. Stephenson. 2006. The Astrolabe Craftsmen of Lahore and Early Brass Metallurgy. Annals of Science 63: 201-13. [CrossRef]

Pollard, A. Mark, and Carl Heron. 1996. Archaeological Chemistry. Cambridge: The Royal Society of Chemistry, pp. 196-238.

Quillen Lomax, Suzanne. 2005. Phthalocyanine and quinacridone pigments: their history, properties and use. Reviews in Conservation 6: 19-29.

Riederer, Josef. 2004. 10000 Jahre Kupfer und Kupferlegierungen: die Erschließung ihrer Entwicklung durch chemische Analysen-Restauro: Forum für Restauratoren. Konservatoren und Denkmalpfleger 110: 394-400.

Römpp Chemie Lexikon. 1995. Stuttgart: Georg Thieme Verlag; New York: Georg Thieme Verlag, p. 3422.

Schwab, R., M. Haustein, N. Lockhoff, and Ernst Pernicka. 2007. The Art of Benin: Authentic or faked? In METAL 07, Preprints of the Interim Meeting of the ICOM-CC Metal WG Amsterdam 17-21 September 2007, Volume 1. Edited by Christian Degrigny, Robert van Langh, Ineke Joosten and Bart Ankersmit. Amsterdam: Rijksmuseum, pp. 91-95.

Simon, Stefan. 2007. Illicit Traffic: a Challenge for Conservation Science and Conservation. Paper presented at ICOM LIC Conference Cairo, Cairo, Egypt, February 27-March 1; pp. 223-27.

U.S. Geological Survey. 2007. Titanium dioxide statistics. In Historical statistics for mineral and material commodities in the United States: U.S. Geological Survey Data Series 140. Edited by T.D. Kelly and G.R. Matos. Available online: http:/ / minerals.usgs.gov/ds/2005/140/ (accessed on 29 December 2017).

Ullwer, Helmut. 2001. Messingherstellung nach dem alten Galmeiverfahren. Erzmetall 54: 319-26.

Welter, Jean-Marie. 2003. The Zinc Content of Brass: A Chronological Indicator? Techne 18: 27-36. 
Yates, Donna. 2016. The Global Traffic in Looted Cultural Objects. In Oxford Research Encyclopedia, Criminology and Criminal Justice. New York: Oxford University Press.

Zwicker, U., H. Greiner, K.-H. Hoffmann, and M. Reithinger. 1985. Smelting, Refining, and Alloying of Copper and Copper Alloys in Crucible Furnaces During Prehistoric Up to Roman Times. In Furnaces and Smelting Technology in Antiquity. Edited by P.T. Craddock and M.J. Hughes. London: British Museum, Occasional Paper \# 48. pp. 103-15. 